\title{
NỖ LỬC THỂ CHẾ HÓA QUYỀN LỰC CHÍNH TRI Ở TÂY NGUYÊN TÙ' THỜI KỲ THUỘC ĐỊA ĐẾN HẬU THUỘC ĐỊA
}

\author{
Nguyễn Văn Bắc $\mathrm{a}^{*}$ \\ ${ }^{a}$ Khoa Lịch sủ, Truò̀ng Đại học Đà Lạt, Lâm Đồng, Việt Nam \\ "Tác giả liên hệ: Email: bacnv@dlu.edu.vn \\ Lịch sử bài báo \\ Nhận ngày 01 tháng 05 năm 2019 \\ Chỉnh sửa ngày 30 tháng 07 năm 2019 | Chấp nhận đăng ngày 15 tháng 08 năm 2019
}

\section{Tóm tắt}

Cho đến đầu thế kỷ XX, Tây Nguyên vẫn được xem là một khu vưc kém phát triển về kinh tế xã hội; Ở đó, các dân tộc thiểu số sinh sống tản mát và có rất ít sự tiếp xúc với thế giới bên ngoài. Trên vùng đất "hẻo lánh" nhung có vị trí địa chính trị đặc biệt quan trọng này, nhiều thế lực chính trị tù bên ngoài đã tùng bước can thiệp và thậm chí xâm chiếm: Trước tiên là nguoời Chăm và chính quyền phong kiến Champa, sau đó đến các triều đại phong kiến Việt Nam, tiếp đến là thưc dân Pháp, và sau đó là chính quyền Việt Nam Cộng hòa và Hoa Kỳ. Bên cạnh việc áp dụng một số lý thuyết điển hình về quyền lực pháp lý, tác giả bài viết cũng dựa trên các quan điểm chính trị có nguồn gốc dân tộc nhằm làm rõ nhũng nỗ lực của tùng thế lực chính trị nêu trên trong việc thể chế hóa và ổn định quyền kiểm soát của họ ở Tây Nguyên tù thời kỳ Pháp thuộc đến khi nuớc Việt Nam được hoàn toàn độc lập và thống nhất vào năm 1975.

Từ khóa: Dân tộc thiểu số; Hậu thuộc địa; Phi thực dân hóa; Quyền lực pháp lý; Tây Nguyên; Thuộc địa.

DOI: http://dx.doi.org/10.37569/DalatUniversity.9.3.565(2019)

Loại bài báo: Bài báo nghiên cứu gốc có bình duyệt

Bản quyền (C) 2019 (Các) Tác giả.

Cấp phép: Bài báo này được cấp phép theo CC BY-NC-ND 4.0 


\title{
ATTEMPTS TO LEGITIMIZE POLITICAL POWER IN THE CENTRAL HIGHLANDS FROM THE COLONIAL TO THE POST-COLONIAL PERIOD
}

\author{
Nguyen Van Bac ${ }^{\mathrm{a}^{*}}$ \\ ${ }^{a}$ The Faculty of History, Dalat University, Lamdong, Vietnam \\ ${ }^{*}$ Corresponding author: Email: bacnv@dlu.edu.vn
}

Article history

Received: May $1^{\text {st }}, 2019$

Received in revised form: July $30^{\text {th }}, 2019 \mid$ Accepted: August $15^{\text {th }}, 2019$

\begin{abstract}
The Central Highlands were, until the early twentieth century, a sparsely populated and poorly developed area with limited contact with the outside world, inhabited by a multitude of diverse ethnic groups (Nguyen, 2019, tr. 5). In this "wilderness", various actors from outside interfered in, or even invaded, this strategically important area - first the Cham people and Champa feudal dynasties, then the empire of Vietnam, the French colonial power, the Viet Minh (and their successors), and finally the South Vietnamese State and the United States of America. In this work, in addition to some common theories on legitimate domination, the author tries to apply several national perspectives to explain each player's attempts in legitimizing and stabilizing their control over the Central Highlands from the French colonial period until Vietnam was entirely independent and united in 1975.
\end{abstract}

Keywords: Central Highlands; Colonial; Democratization; Ethnic minorities; Legitimate rule; Postcolonial.

DOI: http://dx.doi.org/10.37569/DalatUniversity.9.3.565(2019)

Article type: (peer-reviewed) Full-length research article

Copyright $(9) 2019$ The author(s).

Licensing: This article is licensed under a CC BY-NC-ND 4.0 


\section{DÃ̃N NHậP}

Khảo cứu về các loại hình quyền lực pháp lý từng được xác lập ở Tây Nguyên từ thời kỳ thực dân đến hậu thực dân là một công việc khó khăn đối với tác giả bài viết này, bởi điều đó đòi hỏi việc áp dụng nhiều mô hình lý thuyết về quyền lực pháp lý. Tây Nguyên, trên thực tế, từng là một không gian tranh chấp quyết liệt giữa nhiều thế lực chính trị khác nhau nhằm phân định quyền kiểm soát. Có thể kể đến các xung đột giữa các chính quyền phong kiến Champa, Đại Việt, Siam (Xiêm), Khmer, và Lào trong thời kỳ trung đại; Giữa thực dân Pháp, Việt Minh, và người Nhật trong giai đoạn trước khi Hiệp định Geneva được ký kết vào năm 1954; Hay giữa một bên là Hoa Kỳ và chính quyền Việt Nam Cộng hòa, bên thứ hai gồm chính quyền Việt Nam Dân chủ Cộng hoà và Mặt trận Dân tộc Giải phóng miền Nam Việt Nam (từ năm 1969 là chính phủ Cách mạng lâm thời Cộng hòa miền Nam Việt Nam), bên còn lại là các lực lượng dân tộc thiểu số ly khai trong giai đoạn 1954 - 1975.

Những cuộc tranh chấp phức tạp nêu trên cho thấy, đã từng có nhiều quan điểm khác biệt (đôi khi là đối lập) về quyền lực pháp lý được các thực thể chính trị khác nhau áp dụng, làm cơ sở cho việc xác lập quyền kiểm soát của mỗi bên tại vùng đất chiến lược quan trọng này. Trong bài viết dưới đây, tác giả cố gắng khai thác một số lý thuyết điển hình về quyền lực pháp lý nhằm làm rõ nỗ lực của từng lực lượng chính trị trong việc thể chế hóa quyền lực ở Tây Nguyên như: Học thuyết nổi tiếng của Max Weber về ba dạng thức của thể chế quyền lực; Lý thuyết Hậu thuộc địa (Post-colonialism); Các chính sách đối ngoại điển hình của người Mỹ trong thời kỳ chiến tranh lạnh như chính sách Đẩy lùi (Military Rollback); Ngăn chặn (Containment policy); và Học thuyết Domino. Bên cạnh đó, các phương thức cai trị điển hình của chủ nghĩa thực dân (cũ) như "Chia để trị" và "Dùng người bản xứ để trị người bản xứ" cũng được phân tích nhằm làm rõ đặc trưng của các loại hình chính quyền mà người Pháp đã thiết lập ở Tây Nguyên cũng như tác động của các chính sách thực dân đối với sự hình thành một bản sắc chung của các cộng đồng thiểu số tại chỗ. Ngoài ra, mặc dù chưa được xây dựng trên một nền tảng lý thuyết vững chắc, nội dung cơ bản trong chính sách dân tộc của chính quyền Việt Nam Cộng hòa cũng sẽ được khảo cứu để làm rõ cố gắng của thực thể chính trị này trong việc thể chế hóa quyền lực ở Tây Nguyên. Sau cùng, những nguyên lý cơ bản trong chính sách của chính quyền Việt Nam Dân chủ Cộng hòa, Mặt trận Dân tộc Giải phóng miền Nam Việt Nam đối với các dân tộc thiểu số ở Tây Nguyên lần lượt được xem xét kỹ lưỡng trong nghiên cứu này.

\section{QUÁ TRÌNH THỂ CHẾ HÓA QUYỀN LỰC Ở TÂY NGUYÊN TÙ THỜI KỲ THUỘC ĐỊA ĐẾN HậU THUỘC ĐỊA}

\subsection{Lý thuyết của Max Weber về ba dạng thức quyền lực pháp lý}

Có thể nói, trong các lý thuyết về quyền lực pháp lý, lý thuyết của Max Weber là phù hợp hơn cả trong việc giải thích mối liên hệ giữa các triều đại phong kiến Việt Nam và các thủ lĩnh thiểu số ở Tây Nguyên. Lý thuyết về ba dạng thức của quyền lực pháp lý được xây dựng từ đầu thế kỷ XX bởi Max Weber, một nhà kinh tế học, xã hội học nổi tiếng người Đức. Ông cũng được xem là người đã đi tiên phong trong việc giải thích 
quyền lực được kiểm soát và hợp thức hóa như một hệ thống niềm tin. Trong công trình nghiên cứu có tên gọi $B a$ loại hình quyền lực pháp lý (Die drei reinen Typen der legitimen Herrschaft) ${ }^{1}$, Weber lần đầu đưa ra một quan điểm mới về quyền lực pháp lý. Quan điểm này sau đó trở thành lý thuyết nổi tiếng góp phần tạo dựng lên tên tuổi của ông: Lý thuyết về Ba loại hình quyền lực pháp lý (Three types of a legitimate rule). Theo Weber, ba loại hình quyền lực pháp lý bao gồm: i) Chính quyền pháp lý (legalrational authority); ii) Chính quyền truyền thống (traditional authority); và iii) Chính quyền lôi cuốn (charismatic authority) (Weber, 1958, tr. 1). Weber (1958) cũng cho rằng, mỗi nhà cầm quyền đều có cách thức giải thích cho sự vượt trội của họ, nhằm thuyết phục quần chúng tin tưởng vào tính hợp pháp của hệ thống chính trị mà họ đang dẫn dắt. Những lập luận đó thường được chấp nhận và trực tiếp mang lại sự ổn định (về chính trị), nhưng cũng luôn bị nghi ngờ trong những giai đoạn khủng hoảng (Bendix, 1998, tr. 294). Các loại hình quyền lực này được nhận dạng dựa trên những thành tựu cơ bản mà từng trật tự chính trị mang lại. Cụ thể là:

- Chính quyền pháp lý là dạng thức chính quyền được xác lập dựa trên những căn cứ rõ ràng trong luật pháp. Các nhân vật kiểm soát các quy tắc đó (các nhà lãnh đạo) được bổ nhiệm hoặc bầu cử bằng một quy trình mang tính thể chế. Sự tuân thủ của dân chúng không dựa trên năng lực cá nhân của nhà cầm quyền nào mà dựa trên tính hợp pháp và thẩm quyền của họ theo luật định. Các nhà lãnh đạo cũng phải tuân theo các quy tắc giới hạn quyền lực của chính họ, và tách biệt cuộc sống riêng tư của họ khỏi các nhiệm vụ trong hệ thống chính quyền (Weber, 1958, tr. 2-3);

- Kiểu chính quyền truyền thống lệ thuộc nhiều vào nhân cách của người cầm quyền. Các nhà lãnh đạo thường có xu hướng hưởng thụ do quyền lực họ có được là bằng con đường thừa kế. Loại chính quyền này dường như là hợp pháp như "sự tồn tại đương nhiên" của nó. Người cầm quyền là người phụ thuộc vào truyền thống hoặc trật tự đã được thiết lập và cũng là một nhân cách nổi trội; Trật tự hiện hành trong xã hội trao cho anh ta quyền cai trị. Loại quyền lực này rất điển hình trong chế độ gia trưởng kiểu phong kiến, với mối quan hệ song phương giữa chư hầu và lãnh chúa (Weber, 1958, tr. $3-6)$;

- Chính quyền lôi cuốn là kiểu quyền lực được tạo ra bởi một cá nhân sở hữu một số phẩm chất nhất định, ví dụ: Kỹ năng kỳ diệu (ma thuật), khả năng tiên đoán, lòng dũng cảm vô song.... Những khả năng vượt trội này khiến cho nhà lãnh đạo trở thành một cá nhân kiệt xuất. Sức mạnh của anh ta bắt nguồn từ sự sùng bái và niềm tin gần như không thể lay chuyển mà quần chúng đặt vào những phẩm chất phi thường (của anh ta); Chính những điều

\footnotetext{
${ }^{1}$ Bài báo này được đăng lần đầu bởi một tạp chí khoa học của Đức tên là Preussische Jahrbücher số 187, xuất bản 1922; Sau đó được dịch ra tiếng Anh bởi Hans Gerth và đăng lại trên tạp chí Berkeley Publications in Society and Institutions, 4(1), 1-11, 1958.

${ }^{2}$ Về phương diện thuật ngữ, từ "Herrschaft" trong tiếng Đức có thể được dịch thành "cai trị" (rule), hoặc "chính quyền" (authority), hoặc "sự thống trị" (domination).
} 
này tạo nên sức hút của nhà lãnh đạo chứ không phải bất kỳ một truyền thống hay quy tắc pháp lý nào (Weber, 1958, tr. 6-10).

Nhìn lại thời kỳ tiền thuộc địa ở Tây Nguyên, có thể thấy mối quan hệ giữa các Hoàng đế Việt Nam và các thủ lĩnh người Thượng rất điển hình cho dạng thức quyền lực thứ hai - kiểu thống trị truyền thống. Trong mối quan hệ này, chính quyền phong kiến trung ương Đại Việt thường tìm cách kiểm soát trong khi hạn chế tiếp cận vùng đất Tây Nguyên. Cách thức quản lý này, trên thực tế, là tương đối lỏng lẻo. Có lẽ, lý do chính cho việc áp dụng chiến lược này là vì các Hoàng đế Đại Việt không muốn quyền kiểm soát Tây Nguyên rơi vào tay các nước láng giềng, đặc biệt là Xiêm. Nếu một nước láng giềng mạnh như Xiêm chiếm cứ được vùng đất này, chủ quyền lãnh thổ của các Hoàng đế Việt Nam có thể ít nhiều bị đe dọa. Tuy nhiên, nhiều tài liệu lịch sử cũng cho thấy, các vị vua người Việt có rất ít hứng thú đối với việc xây dựng một bộ máy chính quyền quan liêu tại vùng đất mà họ vẫn quan niệm là một xứ "rừng thiêng nước độc" như Tây Nguyên (Nghiêm, 1962). Thậm chí, đến thời Nguyễn, quan hệ hôn phối giữa người Việt và người Thượng (Man) còn bị xem là một hành vi phạm pháp. Người phạm tội có thể bị phạt đánh tới 100 gậy; Quan lại địa phương nếu biết chuyện mà dung túng sẽ bị triều đình nghị tội ${ }^{3}$. Mối quan hệ song phương giữa Hoàng đế Việt Nam và các vị "Vua" của người Thượng, do đó, chỉ dừng lại ở mức độ lệ thuộc giữa tôn chủ và bồi thần, khá điển hình ở Bắc Á thời kỳ phong kiến. Để duy trì quan hệ phụ thuộc đó, cùng với việc thu nhận các cống phẩm theo định kỳ, triều đình Huế cũng không quên phong chức tước (phần nhiều mang tính danh dự) và ban tặng vật cho các thủ lĩnh người Thượng (Vua Lửa và Vua Nước $)^{4}$.

\subsection{Quá trình thể chế hóa quyền lực của Pháp ở Tây Nguyên}

Khác với quan điểm của các triều đại phong kiến Việt Nam, với vị trí nằm ở trung tâm bán đảo Đông Dương và ở một độ cao đặc biệt, Tây Nguyên được người Pháp ví như "mái nhà của Đông Dương". Nhiều nhà chiến lược quân sự tin rằng nếu ai chiếm được Tây Nguyên, người đó không chỉ có thể kiểm soát Việt Nam mà còn kiểm soát cả Lào và Campuchia, thậm chỉ là cả khu vực Đông Nam Á (Colby \& McCargar, 1989; Lê, Trần, \& Nguyễn, 2000, tr. 61). Được đánh giá là khá thành công trong việc áp dụng những công cụ chính sách điển hình của chủ nghĩa thực dân như "Chia để trị " và "Dùng ngươi bản xứ trị người bản xư", cùng với việc thiết lập và trực tiếp nắm giữ (đến cấp tỉnh) bộ máy chính quyền thuộc địa, người Pháp đã chuyển giao quyền lực ở cấp cơ sở (từ cấp huyện trở xuống đến làng xã) cho giới quan lại bản xứ. Bằng phương

${ }^{3}$ Điều 16 (Cưới gả sai luật, tội của chủ hôn và mai mối), Tập 7 (Hộ luật Hôn nhân), Hoàng Việt luật lệ (Luật Gia Long) (Nguyễn, Vũ, \& Trần, 1994, tr. 350).

\footnotetext{
${ }^{4}$ Vua Lửa và Vua Nước (hay Thủy Xá, Hỏa Xá) là danh xưng là người Việt dùng để nói về hai vị tiểu vương Potao Ia và Potao Apui của người Jarai (ngoài ra còn một vị vua ít được nhắc đến là Vua Gió (Potao Angin)). Các vị tiểu vương này trị vì tộc người Jarai ở cao nguyên Pleiku từ khoảng thế kỷ XV đến cuối thế kỷ XIX. Trong giai đoạn đó, nhiều tộc người khác, không chỉ ở Tây Nguyên mà còn ở Lào, Campuchia cũng đến xin thần phục Vua Lửa và Vua Nước. Dưới thời Nguyễn, triều đình thiết lập mối quan hệ chặt chẽ hơn với Tây Nguyên bằng cách đặt ra các nghi thức ngoại giao với hai tiểu vương quốc Jarai. Tuy nhiên, cần phải nói rằng Vua Lửa và Vua Nước thực chất chỉ là những thủ lĩnh bộ lạc, những người nắm giữ sức mạnh tinh thần do được trao truyền vật thiêng trong thực hành tín ngưỡng nông nghiệp, cụ thể là các bộ phận khác nhau của một thanh "gươm thần". Hoàn toàn khác biệt với các vị vua thông thường, hai vị vua này của không hề có quân đội hay quyền lực thế tục nào cả (Cửu \& Toan, 1974, tr. 150; Dournes, 2013, tr. 27; Maitre, 2008, tr. 179-80).
} 
thức này, các nhà thực dân không chỉ triệt để lợi dụng uy tín của các quan lại người địa phương, những người có vài trò rất quan trọng trong đời sống cộng đồng, mà còn tạo ra sự nghi ngờ và chia rẽ trong nội bộ cư dân tại chỗ.

Đối chiếu với lý thuyết của Max Weber về các loại hình quyền lực pháp lý, mô hình quản trị do người Pháp áp dụng ở Tây Nguyên có thể được coi là sự pha trộn giữa hai loại hình quyền lực pháp lý và truyền thống. Trên thực tế, tại mỗi quốc gia dân tộc đều tồn tại một ý thức cố kết cộng đồng về mặt nhà nước. Để việc cai trị được thuận lợi, các nhà thực dân luôn tìm cách phá vỡ tinh thần cố kết đó; Lợi dụng sự khác biệt về nguồn gốc, sắc tộc, trình độ phát triển, để chia rẽ, gây mâu thuần nội bộ trong quốc gia thuộc địa. Ở Việt Nam, sau khi ép triều đình Huế ký kết Hiệp ước Patenôtre (còn được gọi là Hiệp ước Bảo hô) vào đầu tháng 6 năm 1884, Pháp chia nước ta thành ba kỳ là Bắc Kỳ (Tonkin), Trung Kỳ (Annam), và Nam Kỳ (Cochinchine), đặt ở mỗi kỳ một chế độ chính trị khác nhau ${ }^{5}$. Tại Nam Kỳ, xứ thuộc địa trực tiếp (trực trị), thực dân Pháp đặt ra một bộ máy cai trị giống như đối với một tỉnh bên chính quốc. Mọi ảnh hưởng cũng như quyền lợi của triều đình phong kiến Việt Nam ở đây đều bị xoá bỏ. Khác với Nam Kỳ, ở Bắc và Trung Kỳ, song song với bộ máy chính quyền thực dân, hệ thống chính quyền quan liêu Nam triều vẫn được duy trì về danh nghĩa. Trên thực tế, kể từ thời điểm này, vua quan phong kiến Việt Nam trở thành những người làm công cho chính quyền thực dân, thành công cụ giúp người Pháp cai trị đồng bào của chính mình. Chưa dừng lại ở đó, các nhà thực dân tiếp tục gộp ba kỳ của Việt Nam với Campuchia để thành lập Liên bang Đông Dương thuộc Pháp (Tiếng Pháp: Union indochinoise) vào năm 1887. Lào và một phần lãnh thổ phía Nam Trung Quốc là Quảng Châu Loan (Guangzhouwan) cũng lần lượt được sáp nhập vào liên bang này vào các năm 1893 và 1898 . Từ đây, tên các quốc gia trên bán đảo Đông Dương hoàn toàn bị xóa bỏ trên bản đồ thế giới với tư cách là những quốc gia độc lập.

Giống như với Bắc và Trung Kỳ của Việt Nam, Lào, và Campuchia, sau khi về cơ bản bình định Tây Nguyên, người Pháp nhanh chóng tạo lập ở đây một bộ máy chính quyền bảo hộ, và các nhà thực dân cũng chỉ trực tiếp nắm quyền kiểm soát các đơn vị hành chính từ cấp tỉnh trở lên. Khi một tỉnh mới được thành lập, Toàn quyền Đông Dương sẽ bổ nhiệm một người Pháp làm Công sứ (Provincial Résident). Viên Công sứ này sẽ được trao toàn quyền xây dựng và lãnh đạo bộ máy chính quyền thực dân trong địa bàn do ông ta trị nhiệm ${ }^{6}$. Bên cạnh Công sứ người Pháp, triều đình Huế vẫn duy trì việc bổ dụng một quan chức người Việt làm Quản đạo (chức danh đầu tỉnh trong hệ thống chính quyền Nam triều ở Tây Nguyên). Tất nhiên, như đã nói ở trên, chức danh

\footnotetext{
${ }^{5}$ Chế độ thuộc địa được người Pháp thiết lập ở Nam Kỳ, trong khi các chế độ bảo hộ và nửa bảo hộ lần lượt được áp dụng ở Bắc và Trung Kỳ.

${ }^{6}$ Quá trình thiết lập bộ máy chính quyền ở Tây Nguyên có thể được tóm tắt theo từng giai đoạn như sau: Ngay sau khi người Pháp đạt được thỏa thuận với triều đình Huế về chuyển giao quyền lực hành chính ở Tây Nguyên vào năm 1889, quyền quản lý vùng đất này được giao cho Công sứ Quy Nhơn. Hai năm sau đó, chính quyền thuộc địa thiết lập một trung tâm hành chính ở Kon Tum để cai trị các địa bàn Kon Tum và Cheo Reo. Tiếp đó, trong các năm 1917 và 1923, hai thị xã Đà Lạt và Darlac lần lượt được thành lập. Bộ máy hành chính thực dân ở Tây Nguyên, từ đó, được đặt dưới quyền cai quản của viên Khâm sứ Trung Kỳ (Supérieur de l'Annam).
} 
của quan lại Nam triều chỉ mang tính hình thức, mọi quyền lực thực sự đều nằm trong tay người Pháp và vận hành trong khuôn khổ luật pháp của các nhà thực dân.

Ở cấp độ từ huyện trở xuống, cấu trúc quyền lực lại hoàn toàn khác biệt so với các cấp cao hơn. Trong các cộng đồng địa phương, người Pháp tiếp tục duy trì mô hình chính quyền tự trị truyền thống của cư dân thiểu số. Bằng việc ban phát những lợi ích vật chất và trao quyền lực hành chính, người Pháp đã biến đội ngũ già làng khả kính thành những công chức trong hệ thống chính quyền địa phương, mà thực tế là những con tốt trên bàn cờ chính trị thực dân. Đội ngũ già làng/công chức này nhận lương từ ngân sách và phục vụ với vai trò trung gian giữa đồng bào của họ và chính quyền thuộc địa. Trong khuôn khổ những quy phạm pháp luật do người Pháp đặt ra, về danh nghĩa đồng bào thiểu số vẫn được bầu chọn người đứng đầu cộng đồng theo luật tục. Tuy nhiên, tất cả các cuộc bầu cử sẽ chỉ được coi là hợp pháp sau khi danh sách các ứng viên và người trúng cử được phê chuẩn bởi viên Công sứ Pháp.

Từ năm 1950, dưới áp lực của xu hướng giải thực dân hóa, cũng nhằm mục đích tách các khu vực cư trú của đồng bào thiểu số khỏi xã hội Việt Nam, người Pháp đã thành lập một khu tự trị mang tên Hoàng Triều Cuoong Thổ (tiếng Pháp: Domaine de la Couronne hay Domaine de la Couronne du pays Montagnards du Sud-P.M.S.). Khu tự trị này được đặt dưới sự cai trị của cựu hoàng Bảo Đại và được trao cho một quy chế đặc biệt ${ }^{7}$. Về danh nghĩa, Hoàng Triều Cương Thổ bao gồm cả khu vực miền núi phía Bắc và Tây Nguyên, nhưng trên thực tế, Bảo Đại chỉ cai quản được vùng cao nguyên phía Nam vì cao nguyên phía Bắc trong giai đoạn đó hoàn toàn nằm dưới sự kiểm soát của chính quyền Việt Nam Dân chủ Cộng hòa. Tây Nguyên, từ đó vẫn thuộc khối Liên hiệp Pháp nhưng không còn là một phần lãnh thổ của Quốc gia Việt Nam nữa (Touneh, 1970, tr. 92-95).

\subsection{Chiến lược hợp pháp hóa quyền lực ở Tây Nguyên của Hoa Kỳ}

Khi tìm hiểu quá trình phi thực dân hóa và xây dựng quốc gia ở Việt Nam từ sau Cách mạng tháng Tám (1945), đặc biệt là từ sau Hiệp định Geneva (1954), tác giả bài viết vận dụng lý thuyết Hậu thuộc địa nhằm giải thích các chính sách ngoại giao của Hoa Kỳ áp dụng ở Việt Nam trong thời kỳ chiến tranh lạnh. Ở châu Âu, từ những năm 1950 trở đi, giới học giả bắt đầu nghiên cứu nội hàm của của một lý thuyết mới, sau này được biết đến với tên gọi lý thuyết Hậu thuộc địa (Postcolonial Theory). Một trong những vấn đề trung tâm của lý thuyết Hậu thuộc địa bàn về tình hình của các cựu thuộc

\footnotetext{
${ }^{7}$ Vào ngày 21 tháng 5 năm 1951, Đổng lý văn phòng của Quốc trưởng Bảo Đại đã ban hành Sắc lệnh 16/QT/TD, đặt ra một quy chế đặc thù (statut particulier) cho Hoàng Triều Cuơng thổ. Theo sắc lệnh này, các dân tộc thiểu sổ ở Tây Nguyên được hưởng "các quyền ưu việt" để phát triển theo phong tục của riêng họ. Quy chế này cũng khuyến khích người Tây Nguyên tham gia vào hệ thống hành chính của Hoàng Triều Cuoong Thổ như tham gia vào các tòa án phong tục. Các quy định của Sắc lệnh 16/QT/TD xác định rõ vai trò của hệ thống cố vấn cấp tỉnh và huyện, cũng như các vị trí của người đứng đầu các buôn làng. Sau đó, Sắc lệnh này dành sự quan tâm đến các vấn đề kinh tế, y tế và giáo dục. Quyền của chủ sở hữu đất (Polan) sẽ được tôn trọng; Chính quyền đảm bảo tất cả các hoạt động bán hoặc chuyển nhượng đất đều thuận theo phong tục truyền thống bằng cách tham khảo ý kiến của các già làng trước khi phê duyệt mỗi giao dịch. Việc đào tạo cán bộ người Thượng trong các lĩnh vực quân sự, y tế, hành chính, và giáo dục sẽ dựa trên nhu cầu của từng địa phương. Giống như các đạo luật do người Pháp ban hành trước đây, việc giảng dạy các ngôn ngữ dân tộc thiểu số sẽ được duy trì ở cấp tiểu học. Cuối cùng, bản quy chế xác định rằng người Thượng chỉ phải gia nhập quân đội đồn trú ở Tây Nguyên và phục vụ cho việc bảo vệ lãnh thổ của chính họ (Cửu \& Toan, 1974, tr. 138; Đoàn, 1966, tr. 94; Touneh, 1970, tr. 9297).
} 
địa của chủ nghĩa tư bản sau khi được giải thực dân hóa, trong và sau Thế chiến II. Cụ thể là về phương thức các nhà lãnh đạo quốc gia mới lên nắm quyền đối phó với cuộc khủng hoảng chính trị và tư tưởng do chủ nghĩa thực dân để lại, và xây dựng hệ giá trị dân tộc mới trong quá trình kiến quốc (Lianeri, 1999). Giống như ở nhiều nước khác trong khu vực Đông Nam Á, quá trình phi thực dân hóa và kiến thiết đất nước ở Việt Nam diễn ra tương đối phức tạp trong bối cảnh nhiều biến động của cục diện chính trị quốc tế thời kỳ Chiến tranh Lạnh. Kết quả của những tranh chấp về ý thức hệ giữa các khối phương Tây và phương Đông (Tư bản Chủ nghĩa và Xã hội Chủ nghĩa) đã dẫn đến sự chia cắt tạm thời của Việt Nam sau Hội nghị Geneva và một cuộc chiến tranh kéo dài suốt hai thập kỷ sau đó ${ }^{8}$.

Trong chiến lược đối ngoại của Mỹ đối với châu Á thời kỳ này, chính sách Ngăn chănn (còn gọi là Be bò̀ - Containment policy) được xem là có tác động mạnh mẽ nhất đến Việt Nam. Được khởi xướng từ năm 1946 bởi nhà ngoại giao Hoa Kỳ George $\mathrm{F}$. Kennan và chính quyền của Tổng thống Harry $\mathrm{S}$. Truman áp dụng trong giai đoạn hậu Thế chiến II, Ngăn chặn trở thành chính sách đối ngoại chủ đạo của Hoa Kỳ và các đồng minh trong suốt thời kỳ Chiến tranh Lạnh. Đúng như tên gọi của nó, mục đích chính của chiến lược này là ngăn chặn, tiến tới chấm dứt "sự bành trướng" của chủ nghĩa Cộng sản ở Đông Âu, Châu Phi, và Châu Á đang diễn ra mạnh mẽ trong thời kỳ hậu Thế chiến II. Khi được triển khai ở Việt Nam, chính sách này được điều chỉnh, trở thành học thuyết Domino (Domino Theory). Nổi lên trong các thập niên từ 1950 đến 1980 của thế kỷ XX, học thuyết Domino bắt đầu bằng sự can thiệp sâu hơn của Hoa Kỳ vào Chiến tranh Đông Dương nhằm kiềm chế sự phát triển của chủ nghĩa Cộng sản ở Châu Á (Tucker, 1998, tr. 303-306). Theo giả định của người Mỹ, nếu miền nam Việt Nam rơi vào tay Cộng sản thì các nước Đông Nam Á khác như Lào, Campuchia, và Thái Lan cũng sẽ nằm dưới sự kiểm soát của Cộng sản, điều đó sẽ đe dọa các quốc gia còn lại của cái gọi là Thế giới tụ do (Free World) như Philippines, Nhật Bản, và Úc. Từ lập luận này, Hoa Kỳ đã tự trao cho mình sứ mệnh lãnh đạo Thế giới Tự do chống lại sự bành trướng của chủ nghĩa Cộng sản ở Châu Á (Slater, 1993). Để thiết thực ngăn chặn sự lan rộng của làn sóng đỏ từ Trung Quốc xuống Đông Nam Á, kể từ đầu thập niên 1950, Hoa Kỳ đã bắt đầu gián tiếp can thiệp vào cuộc chiến tranh xâm lược Đông Dương của người Pháp, thông qua việc tăng cường hỗ trợ tài chính nhằm giúp Pháp đè bẹp cuộc kháng chiến của nhân dân Việt $\operatorname{Nam}^{9}$. Về phương diện ngoại giao, Washington nhanh chóng công nhận các quốc gia trong Liên bang Đông Dương thuộc Pháp ${ }^{10}$.

\footnotetext{
${ }^{8}$ Xem thêm: Trần Minh Sơn với bài viết "Chiến tranh ủy nhiệm và giải pháp phòng, chống”, tạp chí Quốc phòng toàn dân. Số ra ngày 13 tháng 11 năm 2014. Truy cập ngày 16 tháng 4 năm 2017 tại địa chỉ: http://tapchiqptd.vn/vi/nghien-cuu-trao-doi/chientranh-uy-nhiem-va-giai-phap-phong-chong/6500.html.

${ }^{9}$ Từ năm 1950 đến 1954, tổng viện trợ kinh tế và quân sự của Hoa Kỳ cho Pháp đã vượt quá 3.5 tỷ đô la. Trong đó, viện trợ quân sự đã tăng từ 10 triệu vào năm 1950 lên 1.1 tỷ đô la vào năm 1954, chiếm 78\% chi phí của Pháp dành cho cuộc chiến này (Pentagon, 1971, tr. 53-75).

${ }^{10}$ Vào ngày 7 tháng 2 năm 1950, Tổng thống Hoa Kỳ Truman tuyên bố công nhận chính quyền của Quốc trưởng Bảo Đại ngay sau khi Quốc hội Pháp tuyên bố rằng họ vừa thông qua "nền độc lập của Nhà nước Việt Nam” (Đoàn, 1966, tr. 1966).
} 
Trong bước tiếp theo của kế hoạch xây dựng một tiền đồn chống cộng ở miền Nam Việt Nam, Hoa Kỳ đã lựa chọn và hậu thuẫn mạnh mẽ cho Ngô Đình Diệm, một nhà lãnh đạo quốc gia có bản chất chống Cộng quyết liệt; Giúp ông ta (khi đó đang lưu vong ở Mỹ) hồi hương và tiếp quản quyền lực ở phía Nam vĩ tuyến 17 vào đầu tháng 7 năm 1954. Để giải quyết những thiếu hụt về tài chính, từ năm 1954 đến năm 1960, Washington đã cung cấp cho Sài Gòn bảy tỷ đô la, trong đó viện trợ quân sự là 1.5 tỷ, chiếm $80 \%$ ngân sách quân sự của chế độ Diệm (McNamara, Robert, \& van de Mark, 1995, tr. 43). Về mặt ngoại giao, Hoa Kỳ đã tập hợp các nước chư hầu, thành lập tổ chức Hiệp ước Đông Nam Â (Southeast Asia Treaty Organization - SEATO) ${ }^{11}$. Hơn nữa, cường quốc này còn vận động Liên Hợp Quốc và nhiều quốc gia khác công nhận sự tồn tại của Việt Nam Cộng hòa với tư cách là một chính quyền hợp pháp ${ }^{12}$ (Trần, 2015 , tr. 22, 25-27).

Trong một diễn biến khác, một số tài liệu được giải mật gần đây cho thấy, Edward Lansdale, một chuyên gia của Cơ quan Tình báo Trung ương Mỹ (CIA), người đã hoạt động tích cực ở miền Bắc Việt Nam trong thời kỳ này với mục đích "làm suy yếu Việt Nam Dân chủ Cộng hòa và củng cố Chính quyền Việt Nam Cộng hòa bằng mọi cách thức có thể", đã thực hiện một chương trình tuyên truyền lôi kéo dân thường, đặc biệt là người công giáo di cư vào Nam (Lansdale, 1991; Sheehan, 1988, p. 137) ${ }^{13}$.

Từ đầu những năm 1960, được sự chấp thuận của Quốc hội Hoa Kỳ, Tổng thống Kennedy tiếp tục đẩy mạnh việc triển khai Học thuyết Domino với một cam kết mạnh mẽ hơn. Cụ thể, nước này cam kết gánh vác toàn bộ gánh nặng, liên kết với tất cả các đồng minh, chống lại tất cả kẻ thù để bảo vệ Thế giới tư do; Tăng cường viện trợ cho Nam Việt Nam trên tất cả các phương diện bao gồm hồ trợ quân sự và kinh tế, tuyên truyền, giáo dục và đào tạo, cố vấn (Trần, 2015, tr. 20-21) 14 $^{14}$ Chiến lược này, sau đó, đã được Tổng thống Lyndon $\mathrm{B}$. Johnson phát triển đến đỉnh cao bằng việc đưa lực lượng viễn chinh Mỹ và chư hầu trực tiếp tham chiến; Tiến hành Chiến tranh cục bộ tại Việt

\footnotetext{
${ }^{11}$ SEATO (còn được gọi là Tổ chức Liên Chính phủ Đông Nam Á - Southeast Asia Intergovernmental Organization), được thành lập dựa trên Hiệp ước phòng thủ tập thể Đông Nam Á hay Hiệp ước Manila (Southeast Asian Collective Defense Treaty - Manila Treaty), ký kết vào tháng 9 năm 1954. Tuy nhiên, mãi đến ngày 19 tháng 02 năm 1955, lễ ra mắt của tổ chức này mới chính thức được tổ chức tại thủ đô Bangkok của Thái Lan với sự tham dự của tám nước thành viên. Trong số các quốc gia thành viên, chỉ có Thái Lan và Philippines nằm ở khu vực Đông Nam Á; Những nước còn lại như Anh, New Zealand, Pakistan, Pháp, và Úc đều không thuộc khu vực này. Trong Hiệp ước Manila, các Điều 2, 4, 8, và một phụ lục về Đông Dương đã đặt ba quốc gia Việt Nam, Lào, và Campuchia dưới "khu vực được bảo vệ" của khối SEATO. Xem thêm tại Franklin (2006) và Britannica (2000, tr. 60).

${ }^{12}$ Đến năm 1958, đã có 50 quốc gia công nhận và thiết lập quan hệ ngoại giao với Việt Nam Cộng hòa. Washington cũng tài trợ cho chính phủ Diệm tham dự nhiều hội nghị quốc tế để tạo vị thế cho Việt Nam Cộng hòa, ví dụ: Hội nghị thượng đỉnh Á-Phi được tổ chức tại Bandung (Indonesia) vào tháng 4 năm 1955, Hội nghị Kế hoạch Colombo năm 1958, v.v. Dưới sự hỗ trợ của Hoa Kỳ và Khối phương Tây, chính phủ Việt Nam Cộng hòa cũng đã xin gia nhập Liên hợp quốc nhưng bị Liên Xô phủ quyết trong các phiên họp của Đại hội đồng vào ngày 10 tháng 09 năm 1957 và ngày 09 tháng 12 năm 1958 . Xem thêm: Văn kiện tố chức Tòa đại diện Ngoại giao Việt Nam của Bộ Ngoại giao Việt Nam Cộng hòa năm 1956, Trung tâm Lưu trữ Quốc gia II, Thành Phố Hồ Chí Minh, Mã hồ sơ PTT- Đệ I CH 14445.

${ }^{13}$ Trong cuộc di cư đầu tiên năm 1954, cái gọi là "Hành trình đến tụ do" (Operation Passage to Freedom), có hơn một triệu người tị nạn từ miền Bắc, những người được hỗ trợ và bị ảnh hưởng bởi tuyên truyền kích động của Hoa Kỳ, đã di cư vào miền Nam. Trong số dân di cư này có khoảng 800,000 người Công giáo, chiểm hai phần ba số giáo dân miền Bắc (Frankum, 2007; Nguyễn, 1957, tr. 70-71; \& Trần, 2005, tr. 427-449).

${ }^{14}$ Đến giữa năm 1961, khoảng 65 triệu đô la viện trợ quân sự và 136 triệu đô la viện trợ kinh tế đã được chuyển đến Sài Gòn; Tháng 12 năm đó, 3,200 lính Mỹ cũng đã được triển khai tại Việt Nam. Bộ chỉ huy Viện trợ Quân sự Hoa Kỳ tại Việt Nam (The U.S. Military Assistance Command, Vietnam - MACV) được thành lập vào tháng 2 năm 1962. Số lượng cố vấn Hoa Kỳ cũng tăng mạnh, đạt 1,346 vào năm 1961 và 9,965 vào cuối năm 1962 (FRUS, 1988, tr. 182-85; Hickey, 1982a, tr. 74).
} 
Nam từ năm 1965 đến năm 1968 (Currey, 2013, tr. 333; FRUS, 1985, tr. 1270-1271²; Lê \& ctg., 2000, tr. 201; \& Pentagon, 1971, tr. 1-39).

Cùng với chính sách Ngăn chăn, Bộ Ngoại giao Hoa Kỳ đồng thời còn áp dụng học thuyết Đẩy lùi (Military Rollback). Rollback là một thuật ngữ được sử dụng bởi các nhà hoạch định chính sách ngoại giao của Mỹ trong những thập niên 40 và 50 của thế kỷ XX. Trong khoa học chính trị, "rollback" là chiến lược buộc thay đổi chính sách của một quốc gia hoặc lãnh thổ, thường bằng cách thay thế chế độ cầm quyền (Borhi, 1999). Ở miền Nam Việt Nam, người Mỹ đã áp dụng lý thuyết này trong việc hậu thuẫn các cuộc đảo chính hay các chiến dịch vận động tranh cử nhằm "thay đổi nhân sự" trong chính giới Sài Gòn. Điển hình nhất là việc Washington ủng hộ Hội đồng Quân nhân Cách mạng tiến hành cuộc đảo chính quân sự, lật đổ gia đình họ Ngô vào tháng 11 năm 1963, hay can thiệp vào cuộc bầu cử, giúp liên danh Nguyễn Văn Thiệu - Nguyễn Cao Kỳ lên nắm quyền vào tháng 10 năm 1967 (Ahern, 1998, tr. 54-56; Lê \& ctg., 2000, tr. 198-199).

Song song với các hành động leo thang chiến tranh, một số ý tưởng chung về hiện đại hóa và xây dựng "quốc gia tự do" cũng được người Mỹ thực hiện ở Tây Nguyên (và một vài địa phương khác thuộc miền Nam Việt Nam) như là một trong những yếu tố cốt lõi của lý thuyết Hậu thuộc địa. Về mặt khái niệm, hiện đại hóa ở đây được hiểu là một quá trình chuyển đổi từ một xã hội "truyền thống" hoặc "tiền hiện đại" sang một xã hội "hiện đại". Trong quá trình chuyển đổi đó, tất nhiên, nhiều giá trị truyền thống có thể bị thách thức, thậm chí bị phê phán mạnh mẽ hoặc bị phủ định. Điều đáng nói ở đây là Walt Whitman Rostow, cha đẻ của lý thuyết Hiện đại hóa lại là quan chức cao cấp trong Bộ Ngoại giao Hoa Kỳ dưới thời Tổng thống Kennedy, và sau đó trở thành cố vấn an ninh của Tổng thống Lyndon Johnson. Thời kỳ các vị tồng thống này cầm quyền cũng là giai đoạn cuộc chiến tranh ở Việt Nam được đẩy lên đến cao trào ${ }^{16}$. Về mặt lý thuyết, với sự hỗ trợ thiết thực của các nước công nghiệp phát triển, nhiều tiềm năng nội tại của các quốc gia "truyền thống" có thể được chuyển hóa thành động lực phát triển một cách nhanh chóng. Dựa trên quan điểm này, bên cạnh các phương tiện ngoại giao và quân sự cần thiết, Hoa Kỳ đã triển khai nhiều dự án nhằm cải thiện đời sống của người thiểu số ở Tây Nguyên, bao gồm các chương trình phát triển kinh tế, ngôn ngữ, văn hóa, phúc lợi xã hội. Nhiều nhóm chuyên gia phát triển từ Hoa Kỳ và các nước phương Tây cũng như các gói hỗ trợ về tài chính được gửi đến vùng đất quan trọng chiến lược này ${ }^{17}$.

\footnotetext{
${ }^{15}$ Document 277. Memorandum From the Assistant Secretary of State for Far Eastern Affairs (Robertson) to the Under Secretary of State (Hoover). Washington, November 22, 1955.

${ }^{16}$ Vào thời điểm đó, bản thân Tổng thống Lyndon Johnson cũng là người ủng hộ Lý thuyết Hiện đại hóa (Lindo, 2009).

${ }^{17}$ Đến tháng 10 năm 1966, có 27 cơ quan đại điện đã điều hành 26 chương trình, sử dụng hơn 300 nhân viên Hoa Kỳ, 30 tình nguyện viên quốc tế và hơn 500 người Việt Nam. Nhiều phái đoàn nhân viên xã hội như Phái đoàn viện trợ kinh tế Hoa Kỳ (USOM), Cơ quan Phát triển Quốc tế Hoa Kỳ (USAID), Viện Ngôn ngữ học Mùa hè (SIL), các tổ chức tình nguyện, v.v., đã đến để hướng dẫn cho người dân Tây Nguyên các phương pháp tiên tiến để phòng ngừa và điều trị bệnh; Chuyển giao các kỹ thuật nông nghiệp bền vững, giúp xây nhà, xây dựng bảng chữ cái dựa trên cơ chế Latin hóa các ngôn ngữ bản địa. Xem: Programs of Technical Assistance in South Vietnam. Trong: Texas Tech University, Vietnam Center, Virtual Archive. Mã tài liệu: 1780709052.
} 
Có thể nói mối quan hệ giữa Việt Nam Cộng hòa và Hoa Kỳ về bản chất là quan hệ phụ thuộc giữa một quốc gia chư hầu và một siêu cường. Sự đồng thuận, hợp tác trong nhiều dự án triển khai ở Tây Nguyên chỉ là phần nổi của tảng băng trôi. Trên thực tế, mỗi bên đang theo đuổi những mục đích riêng ở vùng đất chiến lược quan trọng này. Chiếu theo lý thuyết về quyền lực pháp lý của Weber, quan hệ chi phối của Hoa Kỳ với Nam Việt Nam là một sự pha trộn giữa quyền lực truyền thống và quyền lực pháp lý. Một mặt, Washington đã tích cực hợp pháp hóa chính quyền Sài Gòn trên nhiều phương diện như giúp giới cầm quyền ở đó tổ chức trưng cầu dân ý, bầu cử và vận động sự công nhận về ngoại giao từ cộng đồng quốc tế. Mặt khác, để tối đa hóa lợi ích của họ, người Mỹ cũng luôn sẵn sàng can thiệp sâu vào việc sắp xếp bộ máy nhân sự cũng như vào việc ban hành và điều chỉnh chính sách dân tộc của chính quyền Việt Nam Cộng hòa. Phương thức can thiệp này là khá điển hình cho bản chất chủ nghĩa thực dân kiểu mới. Bên cạnh đó, việc triển khai lý thuyết Hiện đại hóa bằng các dự án phát triển kinh tế xã hội đã đóng một vai trò quan trọng làm gia tăng ảnh hưởng của người Mỹ ở vùng đất chiến lược này. Tất cả những biểu hiện đó khiến chính giới Sài Gòn đã nhiều phen lo lắng về khả năng Mỹ có thể công khai ủng hộ một Tây Nguyên tự trị như Pháp đã làm vào năm 1950.

\subsection{Quá trình thể chế hóa quyền lực của chính quyền Việt Nam Cộng hòa ở Tây Nguyên}

Bàn về những nỗ lực thể chế hóa quyền lực chính trị ở Tây Nguyên, chúng ta không thể không đề cập đến chính sách dân tộc của của chính quyền Việt Nam Cộng hòa (thường được gọi là Chính sách Thuợng vu). Có thể nói người đặt nền móng cho Chính sách Thương vu là Ngô Đình Diệm, tổng thống đầu tiên của chế độ này.

Với nhiều quốc gia ở Đông Nam Á, sự hợp nhất các sắc tộc và ngôn ngữ khác nhau cùng tồn tại trên một không gian lãnh thổ thành một quốc gia dân tộc thống nhất được coi là một trong những mục tiêu quan trọng nhất trong tiến trình giải thực dân hóa từ sau Chiến tranh Thế giới thứ hai. Ở miền Nam Việt Nam, sau khi được Quốc trưởng Bảo Đại bổ nhiệm làm Thủ tướng vào giữa năm 1954, Ngô Đình Diệm đã ban hành Nghị định số 21 (ngày 11 tháng 3 năm 1955), chính thức sáp nhập Hoàng Triều Cuơng Thổ vào lãnh thố Trung phần của Quốc gia Việt Nam. Cũng trong nửa cuối của thập niên 1950, chính quyền Sài Gòn lập ra hàng loạt khu tái định cư ở Tây Nguyên để đón nhận những người Việt di cư từ miền Bắc và duyên hải miền Trung ${ }^{18}$. Cộng đồng người Tây Nguyên, từ đây, chính thức được gọi là dân tộc thiểu số trên chính quê hương của họ (Bộ Phát triển Sắc tộc, 1972, tr. 6-7). Nhằm mục đích xây dựng một thực thể chính trị thống nhất trên toàn miền $\mathrm{Nam}$, Tổng thống $\mathrm{Ngô}$ Đình Diệm khẳng định rằng các dân tộc thiểu số bao gồm người Thượng, người Chăm, người Khmer, và người Hoa "phải hòa nhập vào văn hóa Việt Nam" (Hickey, 1982a, tr. 6-8). Mục tiêu này, sau đó, nhanh chóng được thể chế hóa bởi một sắc lệnh, ban hành vào ngày 12 tháng 6 năm

\footnotetext{
${ }^{18}$ Trong đợt di dân đầu tiên diễn ra vào năm 1954, có 54,551 người di cư được chính quyền miền Nam bố trí cho tái định cư ở Tây Nguyên. Chỉ tính riêng năm năm cuối của thập niên 1950, có 30,000 người Việt khác cũng đã được chính quyền Ngô Đình Diệm di dời từ những khu vực dân cư đông đúc ở duyên hải miền Trung đến vùng đất chiến lược này (Lê, 2006, tr. 549-612).
} 
1955, đánh dấu sự khởi đầu của việc xây dựng Chinh sách Thượng vư ${ }^{19}$. Trong khi bãi bỏ một số đặc quyền quan trọng mà người Thượng nhận được dưới chế độ Hoàng Triều Cuơng Thổ, chính sách dân tộc của chính quyền Việt Nam Cộng hòa áp đặt thêm cho họ nhiều nghĩa vụ mới. Ngoài ra, các chương trình phát triển kinh tế xã hội của chính quyền Diệm thường được tích hợp, lồng ghép trong các cuộc hành quân bình định và chống nổi dậy, gây ra sự rối loạn nghiêm trọng đời sống của đồng bào các dân tộc thiểu số Tây Nguyên. Những sai lầm nghiêm trọng về chính sách của chính quyền cùng với sự trưởng thành về nhận thức của một số trí thức cấp tiến người thiểu số đã dẫn đển sự ra đời của phong trào $B A J A R A K A$ vào tháng 5 năm $1955^{20}$.

Giống như Ngô Đình Diệm, các nhà lãnh đạo kế tiếp của Việt Nam Cộng hòa luôn coi Tây Nguyên là một vùng đất chiến lược và tìm mọi cách để giành được quyền kiểm soát. Cùng với đà leo thang của cuộc chiến, từ đầu những năm 1960, Tây Nguyên trở thành một trong những chiến trường chính vì các lực lượng quân Giải phóng miền Nam rất thành thạo trong chiến thuật $\mathrm{du}$ kích ở các địa bàn rừng núi và nông thôn. Nhằm cô lập các căn cứ của quân giải phóng và cắt đứt các nguồn tiếp vận từ miền Bắc thông qua Đường mòn Hồ Chí Minh, Mỹ và Việt Nam Cộng hòa đã rất nỗ lực trong việc bình định Tây Nguyên. Song song với việc triển khai lực lượng quân sự hùng mạnh trong Vùng II chiến thuật, Washington và Sài Gòn đã áp dụng nhiều giải pháp khác để tìm kiếm sự trung thành (win the hearts and the minds) từ cộng đồng người Thượng. Thể theo nguyện vọng của đồng bào, cuối năm 1964, Thủ tướng Nguyễn Khánh đã công bố các chính sách của chính phủ dành cho các dân tộc thiểu số với ba nguyên tắc chính là "bình đẳng", "tôn trọng", và "hỗ trợ đặc biệt". Các nguyên tắc này sau đó được đổi thành "dân tộc hòa đồng, đồng tiến trong quốc gia thống nhất" dưới chính phủ của Chủ tịch Ủy ban Hành pháp Trung ương (Thủ tướng) Nguyễn Cao Kỳ (Bộ Phát triển Sắc tộc, 1972, tr. 10; Nguyễn, 2013, tr. 87). Kể từ khi thành lập vào cuối năm 1967, chính quyền Đệ nhị Cộng hòa tiếp tục kế thừa và phát huy chính sách dân tộc đã được định hình trong thời kỳ quân quản (1964 - 1967). Sự ổn định tạm thời về chính trị tại Nam Việt Nam trong giai đoạn này, trong chừng mực nhất định, đã góp phần tạo điều kiện thuận lợi để chính quyền Sài Gòn ban hành một số chính sách dân tộc tiến bộ hơn các giai đoạn trước đó. Cụ thể là việc triển khai các chương trình phát triển kinh tế xã hội đã phần nào giúp cải thiện sinh kế và kỹ thuật canh tác của người Thượng. Bên cạnh đó, các dự án văn hóa và giáo dục cũng mang lại nhiều hiệu quả tích cực như khôi phục các tòa án luật tục, tạo cơ hội theo đuổi hệ thống giáo dục quốc dân cho trẻ em dân tộc. Cơ quan chuyên trách các vấn đề dân tộc thiểu số của chính phủ cũng được nâng lên thành Bộ Phát triển Sắc tộc vào cuối năm 1967, trong chính phủ của Thủ tướng Nguyễn Văn Lộc (Bộ Phát triển Sắc tộc, 1972, tr. 12; Nguyễn, 2013, tr. 92-93).

\footnotetext{
${ }^{19}$ Tháng 10 cùng năm, Ngô Đình Diệm và những người thân tín tổ chức một cuộc trưng cầu dân ý gian lận, phế truất Quốc trưởng Bảo Đại. Diệm cũng tổ chức bầu Quốc hội Lập hiến cho Quốc gia Việt Nam; Quốc hội này ban hành Hiến pháp đổi tên Quốc gia Việt Nam thành Việt Nam Cộng hòa do ông ta làm Tổng thống (Tucker, 1998, tr. 807).

${ }^{20} B A J A R A K A$ (chữ viết tắt tên bốn sắc tộc lớn trên Tây Nguyên: Bana, Jarai, Rađê (Ê Đê), và Kaho) là phong trào phản đối chính sách phân biệt đối xử người Thượng trên Cao nguyên Trung phần của chính quyền Việt Nam Cộng hòa (Po, 2012, tr. 12).
} 
Mặc dù có nhiều tiến bộ so với thời Ngô Đình Diệm, chính sách dân tộc của nền Đệ nhị Cộng hòa (và người Mỹ) cũng còn chứa đựng nhiều điểm bất cập và hạn chế. Do đặt mục tiêu bình định Tây Nguyên lên trên hết nên chính quyền Sài Gòn đã quá coi trọng các hành động chính trị và quân sự; Các quan chức người Kinh chiếm số lượng áp đảo trong các cơ quan phụ trách các vấn đề dân tộc thiểu số; Chính sách cải cách ruộng đất không thực sự mang lại lợi ích cho phần lớn dân nghèo tại chỗ; Việc thành lập các khu vực sinh sống chính và các ấp tân sinh, cũng như sự xuất hiện của quá nhiều người Kinh và quân viễn chinh Hoa Kỳ trên địa bàn sinh sống của người Thượng đã mang đến nhiều xáo trộn trong đời sống và sinh hoạt văn hóa, làm nghiêm trọng thêm mối quan hệ vốn đã căng thẳng giữa người Thượng và người Kinh; Các loại vũ khí hủy diệt như Rome Plow, bom Napalm và các hóa chất độc hại mà quân đội Mỹ và quân đội Sài Gòn sử dụng trong các hoạt động "tìm diệt và bình định" đã gây ra nhiều thương vong cho đồng bào các dân tộc thiểu số và hủy hoại nghiêm trọng về môi trường. Những mặt trái vừa nêu là nguyên nhân quan trọng dẫn đến sự bùng nổ của các phong trào đấu tranh của các sắc tộc thiểu số, trong đó điển hình là phong trào $F U L R O^{21}$.

\subsection{Lập trường của chính quyền Việt Nam Dân chủ Cộng hoà và Mặt trận Dân tộc Giải phóng miền Nam Việt Nam về vấn đề quyền lực pháp lý ở Tây Nguyên}

Xét từ lập trường về quyền lực pháp lý, chính quyền Việt Nam Dân chủ Cộng hoà và Mặt trận Dân tộc Giải phóng miền Nam Việt Nam (từ năm 1969 là chính phủ Cách mạng Lâm thời Cộng hòa miền Nam Việt Nam) luôn xác định Việt Nam là một quốc gia thống nhất; Giới tuyến quân sự tại Vĩ tuyến 17, như đã được ghi nhận trong Hiệp định Geneva năm 1954, hoàn toàn chỉ mang tính chất tạm thời ${ }^{22}$. Do đó, Hà Nội không công nhận tính hợp pháp của chính quyền Sài Gòn và coi nhiệm vụ giải phóng miền Nam, thống nhất đất nước là mục tiêu cuối cùng của cuộc kháng chiến. Cùng với việc phủ nhận cơ sở pháp lý của chính quyền Sài Gòn, chính quyền Việt Nam Dân chủ Cộng hoà và Mặt trận Dân tộc Giải phóng miền Nam Việt Nam cũng áp dụng nhiều biện pháp nhằm hợp pháp hóa quyền lực của họ ở Tây Nguyên. Chính sách dân tộc của Mặt trận Việt Minh (sau đó là của Mặt trận Dân tộc Giải phóng miền Nam Việt Nam và chính phủ Cách mạng lâm thời Cộng hòa miền Nam Việt Nam) đã có sức ảnh hưởng sâu rộng trong cộng đồng người Thượng. Hơn thế nữa, ý tưởng của Chủ tịch Hồ Chí Minh về một đất nước độc lập, thống nhất, ở đó tất cả các dân tộc anh em sẽ chung sống hòa thuận và bình đẳng, phù hợp với truyền thống lâu đời và nguyện vọng của đông đảo người dân Việt Nam. Để mục đích kháng chiến, kiến quốc này có thể đến được với cộng đồng các dân tộc Tây Nguyên, chính quyền Việt Nam Dân chủ Cộng hòa và Mặt trận Dân tộc Giải phóng miền Nam Việt Nam đã tiến hành nhiều chiến dịch tuyên truyền về chính sách bình đẳng và hòa hợp dân tộc, sẽ được áp dụng sau khi thống nhất đất nước. Ngoài ra, chủ trương về việc ủng hộ sự ra đời của các khu tự trị dành cho các dân tộc

\footnotetext{
${ }^{21}$ FULRO là viết tắt tên tiếng Pháp của Mặt trận Thống nhất Đấu tranh của các Sắc tộc bị áp bức (Front Unifié pour la Libération des Races Opprimées), bùng nổ và hoạt động mạnh mẽ dưới thời Đệ nhị Cộng hòa; Tuy nhiên, theo Po (2012, tr. 13, tr. 94), FULRO là viết tắt của Front Unifié de Lutte des Races Opprimées, vẫn có cùng ý nghĩa như cụm từ trên.

${ }^{22}$ Bản tuyên bố cuối cùng của Hội nghị Geneva ghi rõ: "Cuộc Tổng tuyển củ thống nhất hai miền Nam - Bắc Việt Nam sẽ đuoợc tổ chức vào ngày 7 tháng 5 năm 1956 duoói sự giám sát của một Ủy ban quốc tế gồm Ân Độ, Ba Lan, và Canada” (Logevall, 2012, tr. 604; Patti, 2008, tr. 744)
} 
thiểu số ở miền Nam (như đã thực hiện ở miền Bắc) đã giành được sự đồng tình mạnh mẽ từ cộng đồng này, trong đó đáng kể nhất là từ các dân tộc Tây Nguyên.

Sau Cách mạng tháng Tám, hầu hết công nhân trong các đồn điền, công chức và giáo viên đã rời bỏ các nhà cai trị thực dân để về với lực lượng Việt Minh. Cũng trong giai đoạn này, lập trường chính trị của giới trí thức Thượng có sự phân chia rõ rệt. Trong khi một số chọn con đường tiếp tục phục vụ cho thực dân Pháp như Y Sok Eban, Y Tuic Mlo Duon Du, Y Blieng Hmok, Touprong Hiou, Touprong Ya Ba, Touneh Han Din, Ya Yu Sahau, Bahnaria Ya Don, và những người khác, như Y Ngong, Y Bih Aleo, Y Wang, Y Nue, Y Tlam, Phem, Depp, đã được cảm hóa và quay sang chiến đấu cho độc lập dân tộc, bên cạnh lực lượng Việt Minh (Hickey, 1982b, tr. 390). Cần phải nói thêm rằng, bên cạnh chính sách tiến bộ của Mặt trận Dân tộc Giải phóng miền Nam Việt Nam thì những sai lầm trong các chính sách các Thuợng vu của chính quyền Ngô Đình Diệm cũng gián tiếp đẩy nhiều người thiểu số Tây Nguyên về phía lực lượng cách mạng. Tiêu biểu là vào ngày 19 tháng 5 năm 1961, để phản đối chính sách đồng hóa cưỡng bức của Việt Nam Cộng hòa, 23 đại biểu của các cộng đồng thiểu số tại chỗ do $\mathrm{Y}$ Bih Aleo chủ trì đã tổ chức Hội nghị Thành lập Ủy ban Dân tộc Tự trị Tây Nguyên (Hickey, 1982a, tr. 66; Salemink, 2002, tr. 7). Ngay sau lễ thành lập, Ủy ban này đã tuyên bố ủng hộ Mặt trận Dân tộc Giải phóng miền Nam Việt Nam, đảm bảo quyền tự chủ của các dân tộc thiểu số và bảo vệ truyền thống văn hóa Tây Nguyên, chống lại chiến lược đồng hóa và phân biệt đối xử của chính quyền Sài Gòn. Đầu tháng 1 năm 1964, Ưy ban Dân tộc Tự trị Tây Nguyên đã tập hợp 150 đại biểu dân tộc thiểu số tại chỗ tham dự Đại hội lần thứ II của Mặt trận Dân tộc Giải phóng miền Nam Việt Nam tại tỉnh Tây Ninh. Tại Đại hội này, Chủ tịch Mặt trận Dân tộc Giải phóng miền Nam Việt Nam, Nguyễn Hữu Thọ đã kêu gọi các đại biểu đề xuất giải pháp cho chính sách đoàn kết, hòa hợp dân tộc sau khi Hoa Kỳ rút khỏi miền Nam Việt Nam (Hickey, 1982a, tr. 93). Ngày 06 tháng 6 năm 1968, Mặt trận Dân tộc Giải phóng miền Nam Việt Nam cùng với Liên minh Dân tộc, Dân chủ, và Hòa bình tại Việt Nam đại diện cho tất cả các tầng lớp xã hội, các đảng chính trị, đoàn thể đề xuất việc thành lập Chính phủ Cách mạng lâm thời Cộng hòa miền Nam Việt Nam và Hội đồng Tư vấn chính phủ. Ông $\mathrm{Y}$ Bih Aleo, với tư cách là Chủ tịch Ủy ban Dân tộc Tự trị Tây Nguyên, đại diện cho các dân tộc thiểu số tại chỗ, đã được bầu làm thành viên của Hội đồng Tư vấn của chính phủ (Po, 2012, tr. 44).

Về mặt ngoại giao, sau khi được thành lập, Chính phủ Cách mạng lâm thời Cộng hòa miền Nam Việt Nam (mà Mặt trận Dân tộc Giải phóng miền Nam đóng vai trò nòng cốt) đã tăng cường vận động cộng đồng quốc tế, đặc biệt là khối Xã hội Chủ nghĩa công nhận tính hợp pháp của chính thể này. Sáu tháng sau khi thành lập (vào tháng 6 năm 1969), Chính phủ Cách mạng lâm thời Cộng hòa miền Nam Việt Nam đã được 25 quốc gia chính thức công nhận ${ }^{2 \dot{3}}$.

\footnotetext{
${ }^{23}$ Xem: List of Countries Having Recognized the Provisional Revolutionary Government of the Republic of South Vietnam. Trong: Texas Tech University, Vietnam Center, Virtual Archive. Mã tài liệu: 2310605017.
} 


\subsection{Nhận thức của các dân tộc thiểu số ở Tây Nguyên về quyền lực pháp lý}

Phân tích ngắn gọn sau đây về những lập luận mà các dân tộc thiểu số đã sử dụng để hợp pháp hóa quyền kiểm soát của họ ở Tây Nguyên từ thời kỳ thuộc địa đến hậu thuộc địa sẽ khép lại nghiên cứu này. Có thể nói, cho đến trước khi Việt Nam tạm thời bị chia cắt làm hai miền vào năm 1954, ý thức chính trị của cộng đồng người tại chỗ Tây Nguyên vẫn còn rất mơ hồ. Mặc dù trong thời kỳ phong kiến, một số lần người Thượng đã đột kích các ngôi làng của người Việt ở phía tây của các tỉnh ven biển miền Trung. Đến thời kỳ thực dân, họ cũng đã tiến hành nhiều hoạt động vũ trang chống lại sự cai trị hà khắc của người Pháp (Bùi, Trần, \& Bùi, 2006, tr. 245-247, 251; Cửu \& Toan, 1974, tr. 111-114; \& Đinh, Nguyễn, \& Nguyễn, 2000, tr. 206). Tuy nhiên, những hành động chống đối kể trên còn mang tính chất rời rạc, chủ yếu nhắm vào các mục tiêu kinh tế hoặc chống lại sự đối xử khắc nghiệt từ phía nhà cầm quyền. Từ năm 1950 , khi quy chế Hoàng Triều Cương Thổ được xác lập, mặc dù chính thức công nhận chủ quyền của cựu hoàng Bảo Đại đối với Tây Nguyên, thực dân Pháp vẫn tiếp tục kiểm soát khu vực này thông qua vai trò của các phái viên đặc biệt.

Như đã nói ở trên, cùng với chính sách "Chia để trị", người Pháp triệt để áp dụng phương thức "Dùng người bản xú để cai trị người bản xư" ở Tây Nguyên. Để đào tạo đội ngũ tay sai người Thượng và cũng là để phá vỡ tính tự trị, khép kín trong văn hóa buôn làng, các nhà thực dân mở một số trường tiểu học Pháp - Ê Đê, Pháp - Bana, Pháp - Việt ở Pleiku, Buôn Mê Thuột, và Đà Lạt. Đồng thời, nhiều hoạt động trao đổi văn hóa giữa các địa phương cũng được tổ chức nhằm nhóm họp những già làng, trưởng bản đã được công chức hóa trong những sinh hoạt chung. Trớ trêu thay, trái với mong muốn của người Pháp, những cuộc gặp gỡ của các già làng trong các sự kiện liên làng và giới trí thức thượng lưu trẻ, những người từng được đào tạo ở các trường học Pháp bản xứ hoặc phục vụ trong các đơn vị quân đội thuộc địa, đã làm nảy nở một bản sắc cộng đồng của người Tây Nguyên. Trong chừng mực nhất định, ý thức cộng đồng này ${ }^{24}$ cùng với tư tưởng tự do của đạo Tin lành đã lan rộng ở Tây Nguyên trong thời kỳ giải thực dân hóa, góp phần tập hợp đội ngũ cho các tổ chức như BAJARAKA và FULRO.

Cùng với việc nhiều lần gửi đơn thỉnh nguyện hoặc đoàn đại biểu đến Sài Gòn để yêu cầu chính quyền Nam Việt Nam tôn trọng truyền thống và phong tục của người Thượng, quyền sở hữu đất đai và quyền được đối xử bình đẳng với người Kinh, đồng bào Tây Nguyên cũng đưa ra yêu cầu chính thức về một lá cờ cho riêng họ (như đã được chấp thuận dưới thời kỳ Hoàng Triều Cuơng Thổ). Hơn thế nữa, vào giữa năm 1958, BAJARAKA tiếp tục gửi đơn kiến nghị tới các cơ quan ngoại giao của Liên Hợp Quốc và một số quốc gia như Mỹ, Anh, Pháp, Ân Độ, và Lào tại Sài Gòn để tố cáo các chính sách phân biệt chủng tộc của chính quyền Diệm và yêu cầu các cường quốc can thiệp vào việc tạo lập một "Khu vực tự trị cho người Thượng". Trong một nỗ lực cao hơn, BAJARAKA thậm chí còn đề xuất nguyện vọng về một cái gọi là "Tây Nguyên độc lập" trong khối Liên hiệp Pháp hoặc dưới sự bảo trợ trực tiếp của Hoa Kỳ (Hickey, 1982a, tr. 57; Po, 2012, tr. 36).

\footnotetext{
${ }^{24}$ Sự tự nhận thức là người Tây Nguyên thay vì chỉ tự coi mình là thành viên của một làng hay một tộc người nhất định.
} 
Là "những người ở giữa" (people in between) trong các cuộc tranh chấp diễn ra trên chính quê hương mình, đồng bào Tây Nguyên tiếp tục có một sự phân hóa mạnh mẽ. Dù sẵn sàng nhận viện trợ từ mọi phía, một bộ phận đông đảo người Thượng đã chọn chiến đấu trong hàng ngũ quân giải phóng, trong khi một số khác đứng về phe Việt Nam Cộng hòa trong cuộc đẩu tranh bảo vệ cái gọi là Thế giới tụ do.

Nói tóm lại, nhận thức về quyền lực pháp lý của cộng đồng người Thượng đã có những thay đổi đáng kể từ thời kỳ tiền thuộc địa qua thời thuộc địa đến hậu thuộc địa. Từ hiểu biết rất mơ hồ về quyền lực chính trị, họ dần dần nhận thấy tầm quan trọng của quyền được đối xử bình đẳng, được tôn trọng về mặt văn hóa, và hơn nữa là quyền tự trị, thậm chí độc lập dưới sự bảo trợ của Pháp hoặc Hoa Kỳ. Tuy nhiên, cần phải nói rằng, trong sự trưởng thành đó, ở người Thượng vẫn thiếu hụt ý thức về quốc gia dân tộc Việt Nam. Bằng những điều chỉnh trong chính sách dân tộc, chính quyền Sài Gòn đã thông qua nhiều đề xuất của người thiểu số, ví dụ như, bổ nhiệm một số trí thức người Thượng làm phó tỉnh trưởng các tỉnh Tây $\mathrm{Nguyên}^{25}$ và nâng cấp cơ quan chuyên trách các vấn đề thiểu số của chính phủ lên thành Bộ Phát triển Sắc tộc vào năm $1967^{26}$. Những mâu thuẫn giữa cộng đồng người Thượng và chính quyền Sài Gòn, do đó, cũng ít nhiều dịu đi trong những năm cuối cùng của cuộc kháng chiến chống Mỹ cứu nước.

\section{KẾT LUẬn}

Khác với quan niệm từng tồn tại trong nhiều thế kỷ trước đó về một xứ sở "rừng thiêng nước độc", thực dân Pháp đã sớm nhìn thấy tầm quan trọng của vùng đất Tây Nguyên trong chiến lược chiếm giữ toàn bộ bán đảo Đông Dương. Do đó, ngay sau khi bình định về cơ bản các hoạt động kháng chiến mang màu sắc phong kiến, mà tiêu biểu nhất là Phong trào Cần Vương, vào cuối thế kỷ XIX, chính quyền thực dân đã nhanh chóng thiết lập bộ máy quản lý hành chính ở vùng đất xa xôi này. Sang thời kỳ Chiến tranh Lạnh, vị trí chiến lược của Tây Nguyên còn được người Mỹ đánh giá cao hơn, như một hòn đá tảng giúp ngăn chặn sự lan rộng của làn sóng đỏ từ Trung Hoa xuống khu vực Đông Nam Á. Theo các chiến lược gia Hoa Kỳ, chỉ có kiểm soát được Tây Nguyên mới có thể chặn đứt con đường tiếp vận từ miền Bắc vào miền Nam qua hệ thống Đường mòn Hồ Chí Minh, từ đó từng bước cô lập và tiêu diệt lực lượng du kích của Mặt trận Dân tộc Giải phóng miền Nam Việt Nam. Chính quyền Việt Nam Dân chủ Cộng hòa và Mặt trận Dân tộc Giải phóng miền Nam Việt Nam, tất nhiên, cũng nhận thấy ý nghĩa sống còn của việc giành quyền kiểm soát và xây dựng một bộ máy quản trị hợp pháp ở vùng đất tranh chấp này. Nỗ lực thể chế hóa quyền lực của mỗi bên, do đó, không chỉ dừng lại ở những giải pháp chính trị hay hoạt động ngoại giao nhằm vận động, kêu gọi sự thừa nhận từ cộng đồng quốc tế mà thậm chí còn dẫn đển một số xung đột vũ trang quyết liệt.

\footnotetext{
${ }^{25}$ Y Bham Enuol được bổ nhiệm làm phó tỉnh trưởng Darlac, Paul Nưr trở thành phó tỉnh trưởng của Kontum, v.v. (Hickey, 1982a, tr. 91, 94; Po 2012, tr. 50, 54).

${ }^{26}$ Tất nhiên, những yêu cầu về một lá cờ riêng, về quyền tự trị hay độc lập dưới sự bảo trợ của ngoại bang đều không được chính quyền Sài Gòn chấp thuận.
} 
Cuối cùng, do thiếu tính chính nghĩa nên những cố gắng của người người Pháp, người Mỹ và chính quyền Sài Gòn trong mục tiêu giành lấy con tim và khối óc (win the hearts and the minds) của cộng đồng người Thượng đều không đưa lại kết quả như mong đợi. Nhà sử học Karnow (1984, tr. 323) đã có lý khi nhận định rằng: Những người nông dân ở miền $\mathrm{Nam}$, trong khi "nồng nhiệt đón nhận viện trợ Mỹ lại có cám tình với Việt Cộng”. Với chính sách dân tộc đúng đắn, phù hợp với nguyện vọng của đông đảo các tầng lớp nhân dân, những người Cộng sản đã giành được sự ủng hộ nhiệt thành từ nhân dân miền Nam, trong đó có đồng bào các dân tộc thiểu số ở Tây Nguyên. Đây được xem là một trong những nguyên nhân quan trọng nhất khiến họ có thể hoàn thành mục tiêu "đánh cho Mỹ cút, đánh cho Ngụy nhào" vào năm 1975. Tây Nguyên, từ đó, trở thành một phần lãnh thổ thiêng liêng, không thể tách rời của nước Việt Nam độc lập và thống nhất.

\section{TÀI LIỆU THAM KHẢO}

Ahern Jr, T. L. (1998). CIA and the generals: Covert support to military government in South Vietnam. Washington D.C., USA: Center for the Study of Intelligence, CIA.

Bendix, R. (1998). Max Weber: An intellectual portrait. The British Journal of Sociology, 12(2), 184-188.

Britannica, E. (2000). Students' britannica India. Bombay, India: Popular Prakashan.

Borhi, L. (1999). Rollback, liberation, containment, or inaction? US policy and eastern Europe in the 1950s. Journal of Cold War Studies, 1(3), 67-110.

Bộ Phát triển Sắc tộc (1972). Chính sách phát triển sắc tộc của chính phủ Việt Nam Cộng hòa. Sài Gòn, Việt Nam: Văn phòng Bộ Phát triển Sắc tộc.

Bùi, M. Đ., Trần, H. T., \& Bùi, B. L. (2006). Dân tộc Bana ở Việt Nam. Hà Nội, Việt Nam: NXB. Khoa học Xã hội.

Colby, W. E., \& McCargar, J. (1989). Lost victory: A firsthand account of America's sixteen-year involvement in Vietnam. New York, USA: McGraw-Hill.

Currey, C. B. (2013). Victory at any cost: The genius of Viet Nam's gen. Vo Nguyen Giap. New York, USA: The Warriors publishing.

Cửu, L. G., \& Toan, A. (1974). Cao nguyên miền Thương. Được truy lục từ http://www. tusachtiengviet.com/images/file/n7rTck5c0wgQAB0k/caonguyenmienthuong1.p df.

Dournes, J. (2013). Po tao, một lý thuyết về quyền lự của người Gia Rai ở Đông Duoong (Pötao, une théorie du pouvoir chez les Jörais indochinois) (Nguyên, N. dịch giả). Hà Nội, Việt Nam: NXB. Tri thức.

Đinh, X. L., Nguyễn, V. K., \& Nguyễn, Đ. L. (2000). Đại cương lịch sủ Việt Nam (Tập 2). Hà Nội, Việt Nam: NXB. Giáo Dục.

Đoàn, T. (1966). Việc tù̀ng ngày 1945-1964. Sài Gòn, Việt Nam: Nam chi Tùng thư. 
Franklin, J. K. (2006). The hollow pact: Pacific security and the Southeast Asia treaty organization. Texas, USA: Texas Christian University.

Frankum, R. B. (2007). Operation passage to freedom: The United States Navy in Vietnam, 1954-1955. Texas, USA: Texas Tech University Press.

FRUS. (1985). Foreign relations of the United States, 1955-1957 (Vol. 1). Washington D.C, USA: United States Government Printing Office.

FRUS. (1988). Foreign Relations of the United States, 1961-1963 (Vol. 2). Washington D.C, USA: United States Government Printing Office.

Hickey, G. C. (1982a). Free in the forest: Ethnohistory of the Vietnamese Central Highlands, 1954-1976. Connecticut, USA: Yale University Press.

Hickey, G. C. (1982b). Sons of the mountains: Ethnohistory of the Vietnamese Central Highlands to 1954. Connecticut, USA: Yale University Press.

Hồi ký của cán bộ Văn phòng Quốc hội (2000). Nhơ cùng năm tháng. Hà Nội, Việt Nam: NXB. Chính trị Quốc gia.

Karnow, S. (1984). Vietnam: A history. New York, USA: Penguin Books.

Kopstein, J., \& Lichbach, M. (2014). What is comparative politics? In J. Kopstein, M. Lichbach, S. E. Hanson (Eds.), Comparative politics: Interests, identities, and institutions in a changing global order. Cambridge, UK: Cambridge University Press.

Lansdale, E. G. (1991). In the midst of wars: An American's mission to Southeast Asia. New York, USA: Fordham University Press.

Lê, Đ. C. (2006). Người thương miền nam Việt Nam. California, USA: NXB. Văn mới.

Lê, M. H., Trần, B. Đ., \& Nguyễn, V. T. (2000). Đại cương lịch sủ Việt Nam (Tập 3). Hà Nội, Việt Nam: NXB. Giáo dục.

Lianeri, A. (1999). Douglas Robinson, translation and empire: Postcolonial theories explained. International Journal of Translation Studies, 11(2), 391-394.

Lindo, F. H. (2009). Educational television in El salvador and modernisation theory. Journal of Latin American Studies, 41(4), 757-792.

Logevall, F. (2012). Embers of war: The fall of an empire and the making of America's Vietnam. New York, USA: Random House.

Maitre, H. (2008). Rùng người Thượng (Les Jungles mois) (Lưu, Đ. T., Dịch giả). Hà Nội, Việt Nam: NXB. Tri thức.

McNamara, Robert, S., \& van de Mark, B. (1995). Nhìn lại quá khứ - Tấn thảm kịch và nhũng bài học về Việt Nam (In retrospect: The tragedy and lessons of Vietnam) (Hồ, C. H., Huy, B., Thu, T., và Minh, N., Dịch giả). Hà Nội, Việt Nam: NXB. Chính trị Quốc gia.

Nghiêm, T. (1962). Tìm hiểu đồng bào Thượng. Quê Hương, (31), 147-148. 
Nguyễn, P. (1957). Liên lạc giữa Mỹ và Việt Nam. Sài Gòn, Việt Nam: Nguyễn Phương.

Nguyen, V. B. (2019). From Colonial to Post-Colonial Rule: The Transformation of Rule in an important strategic area in South Vietnam. Bern, Switzerland: Peter Lang $\mathrm{GmbH}$.

Nguyễn, V. T., Vũ, T., \& Trần, H. (1994). Hoàng Việt luật lệ (Luật Gia Long) (Nguyễn, Q. T. và Nguyễn, V. T., Dịch giả). Hà Nội, Việt Nam: NXB. Văn hóa Thông tin.

Nguyễn, V. T. (2013). Mấy nhận xét về chính sách dân tộc của chính quyền đệ nhị Cộng Hòa đối với các dân tộc thiểu số Tây Nguyên (1964-1975). Tạp chí Phát triển Khoa học và Công nghệ, 16(3X), 79-95.

Patti, A. L. (2008). Tại sao Việt Nam? (Why Vietnam?) (Lê, T. N., Dịch giả). Đà Nẵng, Việt Nam: NXB. Đà Nẵng.

Pentagon, P. (1971). U.S. Involvement in the Franco-Viet Minh war, 1950-1954 (Vol. 1). Boston, USA: Beacon Press.

Po, D. (2012). Tù FLM đến Fulro: Cuộc đấu tranh của dân tộc thiểu số miền nam Đông Duoong 1955-1975. California, USA: IOC-Champa.

Salemink, O. H. J. M. (2002). Vietnam: Indigenous minority groups in the Central Highlands. Retrieved from https://www.refworld.org/docid/3c6a48474.html.

Sheehan, N. (1998). A bright shining lie: John Paul Vann and America in Vietnam. New York, USA: Random House.

Slater, J. (1993). The domino theory and international politics: The case of Vietnam. Security Studies, 3(2), 186-224.

Touneh, H. T. (1970). Phát triển xã họi Thuợng trong triển vọng phát triển quốc gia (Luận văn tốt nghiệp). Cao đẳng Quốc phòng Đà Lạt, Việt Nam.

Trần, N. T. (2015). Hoạt động ngoại giao của chế độ "Việt Nam Cộng hòa" thời kỳ Ngô Đình Diệm (1955-1963). Tạp chí Phát triển Khoa học và Công nghệ, 18(4X), 19-29.

Trần, T. L. (2005). The catholic question in north Vietnam. Cold War History, (5), 427449.

Tucker, S. C. (1998). The encyclopedia of the Vietnam war: A political, social, and military history. California, USA: ABC-CLIO Press.

Weber, M. (1958). The three types of legitimate rule (G. Hans, Trans). Berkeley Publications in Society and Institutions, 4(1), 1-11. 